\title{
Olimpizm a edukacja (na przykładzie dorobku Polskiego Komitetu Olimpijskiego)
}

\author{
Olimpizm poszybował przez świat jak \\ błyszczący sterowiec, reforma szkolnictwa \\ torowała sobie droge jak kret. \\ Pierre de Coubertin
}

Filozofia olimpijska opiera się na ciągłym wychodzeniu naprzeciw aspiracjom ludzi, nie zaś na ich negowaniu lub lekceważeniu. Wyjście naprzeciw aspiracjom ludzi określa zasada równych szans. Wyrównywanie szans udziału w igrzyskach stanowi podstawowy element olimpizmu. Są wartości wspólne wszystkim ludziom i te należy rozwijać z równą siłą, jak wartości indywidualne charakterystyczne dla mistrzów.

Wyrównywanie szans to podstawowy warunek olimpizmu przypadający wszystkim, a nie tylko pewnej elitarnej części. Równość szans odnosi się nade wszystko do wymiaru duchowego człowieka, nie niweluje natomiast różnic kulturowych, politycznych i ekonomicznych. Nie występuje przeciw rynkowej wolnej grze lub mecenatowi działalności dobroczynnej. Chodzi raczej o wyrównywanie różnic w dostępie do edukacji olimpijskiej i wykształcenia sportowego, na podobnych zasadach jak przebiega edukacja oświatowa.

Egalitaryzm olimpijski najlepiej sprawdza się w upowszechnianiu wartości pod hasłem: All games - all nations. Należy popularyzować te wartości ustawicznie, wprowadzać do ciągłego myślenia, a nie jedynie apelować o ich podtrzymywanie w sytuacjach kryzysowych. 
Wolność wpisana w strukturę olimpizmu obejmuje też wolność do krytyki, ale takiej, która ulepsza jego naturę, a nie niszczy. Trzeba dziś odpowiedzieć na pytanie, w jakim stopniu zmasowana krytyka przyczynia się do tego, że olimpizm pod jej wpływem staje się odporniejszy na choroby ponowoczesnego świata powstające głównie na podłożu moralnym. W tym kontekście należy krytycznie ocenić epokę, która przeszła do historii olimpizmu jako epoka „panowania pieniądza” oraz sięgania po władzę nad sportem ze strony telewizji i wielkiego biznesu. Okres ten na szczęście należy do przeszłości, ale wiele z jego wpływów i ustaleń powoduje dalej erozję olimpizmu głównie jako praktyki społecznej oraz osłabia jego autorytet.

Oddzielenie olimpizmu od edukacji nadal zachowuje aktualność. W igrzyskach biorą udział ekipy narodowe oraz terytoria o uznanym statusie politycznym. Olimpizm uniwersalny musi być znakiem sprzeciwu wobec wielu tendencji w społeczeństwie globalnym. Prawo naturalne czy prawa człowieka dotyczą praw podstawowych, ale dzisiaj pod hasłem walki o prawa człowieka rozumie się sprawy, które niekoniecznie mają wspólną wykładnię i często na ich interpretacji ciąży polityka.

Pierre de Coubertin podkreślał pokojowy charakter ruchu olimpijskiego i akcentował doniosłą rolę edukacji dla pokoju. Wskazywał zarazem jego znaczenie polityczne w tworzeniu nowego świata opartego na współpracy, współzawodnictwie i wzajemnym szacunku dla odrębności narodowych, wspólnot religijnych i ustrojów politycznych. Olimpizm nie jest neutralny politycznie. Jego siła oparta jest na filozofii rozejmu - ekecheirii - która pomyślnie przeszła próbę ogniową w długiej tradycji, liczącej blisko dwanaście wieków w antycznej Grecji. Nowożytny olimpizm odwołał się do praktyki „rozejmu” olimpijskiego w nadziei, że skoro edukacja europejska opiera się na filozofii i humanizmie dawnej Grecji, to zgodnie z tym duchem wprowadzi do swoich programów wychowanie dla pokoju jako wartość elementarną. Olimpizm praktykowany podczas igrzysk olimpijskich dostarczał przykładów, że spory i konflikty występujące podczas walki można i należy rozstrzygać według reguł przyjętych na podstawie umowy społecznej, zapewniającej równy udział, sprawiedliwy przebieg i wzajemny szacunek dla wszystkich uczestników.

Od dawna istnieją dwa bieguny europejskiej wyobraźni. Jeden to Europa ojczyzn, drugi to Stany Zjednoczone Europy. Jest to dylemat pozorny. Wartość leży i po stronie różnorodności, jak to było w dawnej Grecji zorganizowanej wokół polis, miast-państw, lecz także w strukturze bardziej zharmonizowanej, jak w czasach helleńskich, opartych na wspólnej kulturze i unii gospodarczej.

Kultura olimpijska - oto co się kryje pod tym pojęciem:

- szacunek dla podstawowych wartości ogólnoludzkich,

- tożsamość osobowa otwarta na prawomocną obecność innych osób,

- tolerancja i współtworzenie demokratycznego kompromisu,

- nadrzędność dobra indywidualnego i obowiązek wobec dobra wspólnego,

- służba w obronie ojczyzny,

- dialog jako podstawa wychowania obywatelskiego - paidei, sprzeciw wobec ideowego fanatyzmu. 
Czym natomiast nie powinna być kultura olimpijska:

- polityką zdobywania rozgłosu społecznego nie inaczej niż na podstawie własnych zasług,

- wykorzystywaniem różnic w życiu społecznym innych od tych, które zdobywa się poprzez samowykształcenie (trening sportowy),

- klientelizmem i korupcją polityczną jako praktyką obniżającą poczucie godności człowieka, uczestnika publicznej debaty na agorze (stadion olimpijski),

- sięganiem do nienawiści i odwoływaniem się do przemocy w sporach, w których w grę wchodzą wartości uniwersalne: dobro, piękno, prawda i dzielność.

Kulturę polityczną tworzy cała opinia publiczna. Do niedawna dominowały w niej akcenty europejskie, dzisiaj ma wymiar globalny. Olimpizm należy do całego świata, dowodził w swych pismach Pierre de Coubertin. Doświadczamy tej prawdy coraz bardziej wraz z biegiem nowożytnej historii olimpizmu.

Polityka nie jest wszystkim, ale wpływa na atmosferę życia publicznego. Podnosi jej znaczenie lub ją zatruwa i niszczy. Istotne staje się głównie to, w jakim kierunku pójdzie ruch olimpijski i czy wzmocni on naszą kulturę, czy tylko da się pociągnąć za sobą ponowoczesnej cywilizacji. Nie jest to dylemat nowy, ale nigdy wcześniej nie miał tak otwartego charakteru jak to jest obecnie. Następne igrzyska, jak to już widać dzisiaj wyraźnie, przytłacza kultura techniczna.

Odwołajmy się w tym momencie do samego Pierre'a de Coubertina, który doświadczył na sobie „sojuszu” wielkiego, nowoczesnego przemysłu i budzącego się do samodzielnego życia ruchu olimpijskiego, najpierw w Paryżu w 1900 roku, a cztery lata później w Saint Louis. Było to doświadczenie bardzo kosztowne. Nad igrzyskami górowała wieża Eiffla, a zawody olimpijskie odbywały się w jej cieniu, uzupełniały program imprez towarzyszących światowej wystawie przemysłowej. Nigdy więcej nie należy łączyć w jednym miejscu i w jednym czasie tak różnych wydarzeń - dowodził Pierre de Coubertin.

Uwagę twórcy nowożytnego olimpizmu w różnych okresach jego życia zajmowały głównie dwie sprawy. Najpierw pojawia się wierność ideałom antycznym, olimpizm pojmowany jest przez niego jako „stan ducha”. Podkreśla podmiotowy charakter wychowania sportowego, opartego na rozwoju, radości oraz współzawodnictwie w dążeniu do doskonałości osobowej. Później do głosu doszły sprawy związane z formowaniem się struktury ruchu olimpijskiego jako nowoczesnego teatru, w którym na oczach milionowej widowni przebiega gra o wartości, które mają uniwersalny charakter i globalny wymiar. Powołany przez niego Międzynarodowy Komitet Olimpijski był pierwowzorem uniwersalnej organizacji pozarządowej o zasięgu światowym.

W społeczeństwie nowoczesnym te dwa spojrzenia, te dwa sposoby myślenia olimpijskiego nie muszą być wobec siebie antagonistyczne. Jedno jest pewne: tylko ich współmierność umożliwi ruchowi olimpijskiemu długie trwanie.

Sport jest zawsze atrybutem świata ludzkiego i jedną z uniwersalnych form kultury. 
We współczesnej edukacji szuka się nowych metod nauczania i kształcenia. Odchodzi się od przekazywania suchej wiedzy encyklopedycznej, która jeżeli nie jest poparta praktyką, szybko ulatuje z pamięci. Lepsze są metody aktywne oparte na projektach i programach edukacyjnych tworzonych i realizowanych przez dzieci i młodzież w grupach. Dobrym przykładem takiej edukacji jest działalność klubów olimpijczyka pozostających pod bezpośrednią opieką Polskiego Komitetu Olimpijskiego. Kluby łączą sport z kulturą i sztuką, filozofię olimpijską z praktycznym działaniem w środowisku lokalnym. Kładą nacisk na przekazywanie wartości uniwersalnych, których skarbnicą jest olimpizm. Stwarza się szereg okazji do wspólnego działania, które jest ważniejsze od indywidualnych osiągnięć. Potwierdza się tym samym założenie Pierre'a de Coubertina, że udział jest ważniejszy niż zwycięstwo. Udział wzmacnia więzi wspólnotowe, zwycięstwo ma wymiar indywidualny.

Kluby olimpijczyka wykorzystują moc edukacyjną olimpizmu oraz wzory osobowe uznane w świecie sportu. Poprzez to wpływają na samorefleksję, samopoznanie, kreatywność i kształtowanie charakteru dzieci i młodzieży. Podstawą społecznej i kulturowej działalności klubów jest olimpizm praktyczny dający szansę przeżywania wartości i oddziaływania na emocje wychowanków. Dzięki temu edukacja olimpijska jest nie tylko okazjonalnym wydarzeniem na terenie szkoły i środowiska lokalnego, lecz tworzy zarazem tradycję i historię społeczeństw objętych wpływem edukacji olimpijskiej.

Wychowanie w duchu olimpijskim tylko z pozoru wydaje się łatwym zadaniem. Szczególnie dzisiaj, kiedy wizerunek igrzysk kształtowany bywa przez masowe środki przekazu, które szukają w sporcie sensacji i pola dla reklamy. Obrona ruchu olimpijskiego musi stale odpowiadać na pytania, które podają w wątpliwość misyjny charakter i kulturowy wymiar sportu. Odwoływanie się do historii zasobów tradycyjnych wartości humanistycznych już nie wystarcza, należy ciągle wzmacniać pozytywny obraz igrzysk olimpijskich, zapoznając dzieci i młodzież oraz szeroką opinię społeczną z dorobkiem, jaki wnosi olimpizm do edukacji globalnej. Ważne będzie wtedy to, jak radzi sobie sport z zagrożeniami i erozją wartości moralnych w relacjach międzyludzkich. Należy poszerzać kręgi orędowników idei olimpijskiej odważnie przeciwstawiających się negatywnym zjawiskom w praktyce i filozofii współczesnego olimpizmu.

Nasze spotkanie zmierza w tym kierunku. Przewodnikiem - najlepszym z najlepszych - może być dla nas Barbara Skarga, która głosiła: „Wszakże to starożytność nauczyła nas myśleć filozoficznie i dostrzegać w filozofii coś więcej niż rodzaj wiedzy. Tkwi w niej silny ładunek etyczny, dzięki któremu może się ona stać także sposobem życia - i była nim, w tych odległych czasach".

Zawsze jednak kiedy jako ludzie odwracamy się plecami do przeszłości, tracimy na tym wszyscy. Edukacja olimpijska przebiega kilkoma drogami. Pierwsza z nich obejmuje działalność Polskiego Komitetu Olimpijskiego (1919), Klubu Fair Play (1990), Polskiej Akademii Olimpijskiej (1984), związków i stowarzyszeń 
sportowych. Druga droga przebiega pod kierunkiem nauczycieli, trenerów, instruktorów i działaczy, którzy edukację olimpijską wprowadzają do szkół, klubów, stowarzyszeń i organizacji społecznych.

Trzecia droga obejmuje kształcenie instruktorów, trenerów i nauczycieli na poziomie podstawowym i wyższym, głównie w akademiach wychowania fizycznego. Szlaki prowadzą też na teren uniwersytetów i wyższych szkół pedagogicznych, które dostrzegły w edukacji olimpijskiej treści wzbogacające programy nauczania i ożywiające proces wychowawczy. Czwarta droga dotyczy działalności naukowej, polegającej na prowadzeniu studiów nad olimpizmem i wychowawczym oddziaływaniem sportu na rozwój indywidualny i społeczny człowieka.

W Polsce dominującą rolę odgrywają w zakresie edukacji olimpijskiej działacze PKOI, PAOI, Klubu Fair Play. Wśród wielu inicjatyw należy wyróżnić: konkursy olimpijskie, loterię olimpijską, doroczne Dni Olimpijczyka, propagowanie w różnych formach zasad „czystej gry”, badanie postaw moralnych dzieci i młodzieży uprawiającej sport, wyróżnianie zawodników, trenerów i działaczy za wyjątkowe zachowania fair play, popularyzowanie kodeksów postępowania etycznego na boisku i w życiu społecznym, wprowadzanie problematyki wychowania olimpijskiego do programów kształcenia nauczycieli i na studiach dla dziennikarzy sportowych. A ponadto organizowane są konferencje i seminaria dla dyrektorów szkół, wystawy w dziedzinie sztuki sportowej, promocje książek, konkurs literacki im. Jana Parandowskiego dla uczniów szkół podstawowych i gimnazjów, ogłaszany każdego roku, który znalazł się na liście dwudziestu najciekawszych wydarzeń edukacyjnych na świecie przygotowanej przez MKOI, przyznawane są „Wawrzyny Olimpijskie" za osiągnięcia w dziedzinie sztuki o tematyce sportowej, nagradzane są dzieła ogłoszone w ostatnim czteroleciu olimpijskim.

Wszystkim propozycjom edukacyjnym od przedszkola do uniwersytetu towarzyszy główne przesłanie Pierre'a de Coubertina, że wychowanie powinno odbywać się przez rozwój, a rozwój powinien odbywać się przez radość.

Wykorzystajmy okazję, aby z tym przesłaniem pedagogicznym wejść do szkoły frontowymi drzwiami, a wtedy okaże się, że odmienimy nie tylko ducha sportu, ale całe wychowanie skierujemy w stronę człowieka. 